https://doi.org/10.37208/tgn27127

\section{The powdercap strangler Squamanita paradoxa, a bizarre parasitic mushroom found for the first time in the Glasgow area}

\section{O'Reilly ${ }^{1} \&$ J. Mitchell ${ }^{2}$}

${ }^{1}$ Scottish Environment Protection Agency, Angus Smith Building, 6 Parklands Avenue, Eurocentral, Holytown, North Lanarkshire ML1 4WQ

${ }^{2} 104$ Montford Avenue, Glasgow G44 4NZ

E-mail: myles.oreilly@sepa.org.uk

The powdercap strangler Squamanita paradoxa belongs to a small genus of rather rare and enigmatic fungi. Although the genus has been known for nearly 80 years, its unusual morphology has caused a good deal of confusion and debate among mycologists. The strange chimera-like mixture of microscopical tissues suggested affinities to quite different fungal orders. While some authors had speculated that the unusual features may indicate that mycological parasitism was involved, it was only the examination of new material of Squamanita contortipes, from Washington State, U.S.A. in the 1990s, that enabled the mystery to be finally resolved (Redhead et al., 1994; Gee, 1995). It was confirmed that Squamanita species are parasites of other fungi, invading the emergent fruiting body of the host and supplanting it with their own fruiting body.

The advent of molecular analysis has since allowed the phylogeny of the genus to be elucidated (Matheny \& Griffith, 2010). Only seven Squamanita species are known from Europe with four of these occurring in Britain (Henrici, 2013). The different species are usually associated with different host fungi, although $S$. paradoxa and a similar species, $S$. pearsonii, both infest the earthy powdercap, Cystoderma amianthinum. $S$. paradoxa is the most widespread British species, with around 25 U.K. sites, and with the first British record from Mull in 1969. Currently it is known from only three other Scottish locations: Aberdeenshire, 1999; Peebles, Scottish Borders, 2001; and Lochwinnoch, Renfrewshire, 1996 and 2013 (Silverside, 1998; Fungal Records Database of Britain and Ireland, 2019).

On 31st August 2017 during a fungal foray by J.M. at Cathkin Braes Country Park on the south-east side of Glasgow, two specimens of S. paradoxa were found on a strip of grass close to Queen Mary's Seat (NS61825856). No unparasitised Cystoderma amianthinum were observed. The only other fungi present on the grassy area were a few glutinous waxcap Hygrocybe glutinipes (var. glutinipes). The
S. paradoxa were around $6 \mathrm{~cm}$ high with a cap diameter of around $4 \mathrm{~cm}$. They were readily recognized, without the need for microscopical examination, as the stipe showed the distinctive orange scaly Cystoderma base and the abrupt colour change to lilac-grey where the parasitic Squamanita takes over, as if grafted onto the Cystoderma stipe (Fig. 1). The site was revisited a year later on 29th August 2018. The grass strip then harboured quite a few brown mottlegill Panaeolina foenisecii, but despite an exhaustive search there was no sign of any further $S$. paradoxa or any other fungi.
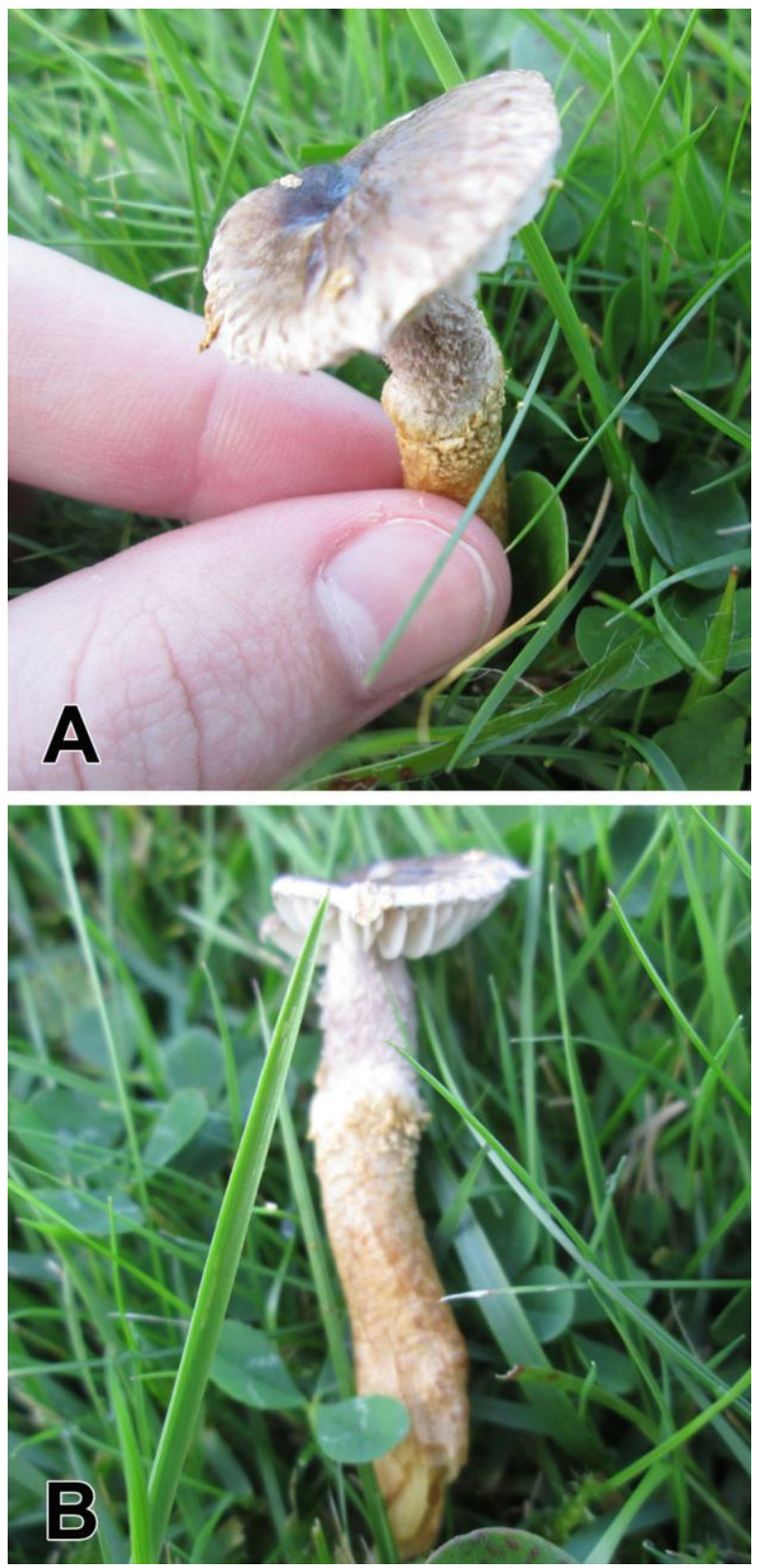

Fig. 1. Powdercap strangler Squamanita paradoxa from Cathkin Braes Country Park, Glasgow, August 2017. (A) Specimen 1. (B) Specimen 2. (Photos: J. Mitchell)

The nearest previous $S$. paradoxa record is from Muirshiel Country Park, Lochwinnoch, where it was found in 1996 by Alan Silverside and again in 2013 during a survey by the Clyde and Argyll Fungus Group. 
The new find of $S$. paradoxa suggests that this and possibly other Squamanita species may be more widespread in Scotland.

All the Squamanita species are relatively small and only $S$. paradoxa appears in recent field guides (e.g. Sterry \& Hughes, 2009; Buczacki et al., 2012). Hence they are likely to be overlooked or unrecognised by all but the expert field mycologist. Detailed descriptions and a key for the British Squamanita species are provided by Watling \& Turnbull (1998). The British species all have grey-violet caps. S. contortipes which infests Galerina spp., has been found only once in Britain, in 1950 at Rothiemurchus, Speyside (Henrici, 2013). S. odorata, which parasitises Hebeloma spp., has only recently been found for the first time in Britain, in 2010 in Nottinghamshire, England (Leach, 2013). S. pearsonii, which has been recorded from Speyside and Aberdeenshire (Holden, 2005) as well as Caernarvonshire, Wales, resembles S. paradoxa but can usually be distinguished in the field by its much shaggier stipe and cap (Holden, 2005; Argaud \& Wiest, 2018). It is hoped that highlighting this new find might alert naturalists to look out for these rare and unusual parasitic fungi.

Roy Watling and Liz Holden kindly assisted with the preparation of this note.

\section{REFERENCES}

Argaud, D. \& Wiest, R. (2018). Première récolte dans le Nord-Est de la France d'une espèce aussi spectaculaire que rarissime: Squamanita pearsonii Bas (Agaricales, Basidiomycota). Bulletin de la Fédération Mycologique de l'Est 16, 38-52.

Buczacki, S., Shields, C. \& Ovenden, D. (2012). Collins Fungi Guide. The Most Complete Guide to the Mushrooms \& Toadstools of Britain \& Ireland. Harper Collins Publishers, London.

Fungal Records Database of Britain and Ireland (2019). www.frdbi.info/ (Accessed 30.1.2019).

Gee, H. (1995). Mycological mystery tour. Nature 375, 276. https://doi.org/10.1038/375276a0

Henrici, A. (2013). Squamanita in Britain and Europe. Field Mycology 14, 56-63. https://doi.org/10.1016/j.fldmyc.2013.03.008

Holden, L. (2005). Squamanita pearsonii collected in Aberdeenshire. Field Mycology 6, 10-11. https://doi.org/10.1016/S1468-1641(10)60285-X

Leach, J. (2013). Squamanita odorata found in Britain. Field Mycology 14, 53-55. https://doi.org/10.1016/j.fldmyc.2013.03.007

Matheny, P.B. \& Griffith, G.W. (2010). Mycoparasitism between Squamanita paradoxa and Cystoderma amianthinum (Cystodermateae, Agaricales). Mycoscience 51, 456-461. https://doi.org/10.1007/S10267-010-0052-9

Redhead, S.A., Ammirati, J.F., Walker, G.R., Norvell, L.L., \& Piccio, M.B. (1994). Squamanita contortipes, the Rosetta Stone of a mycoparasitic agaric genus. Canadian Journal of Botany 72, 18121824. https://doi.org/10.1139/b94-223

Silverside, A. (1998). Biological Conservation. Assessment of Fungal Biodiversity www.lastdragon.org/uws/bcons/bcfungi3.html (Accessed 30.1.2019).

Sterry, P. \& Hughes, B. (2009). Collins Complete Guide to British Mushrooms and Toadstools. Harper Collins Publishers, London.

Watling, R. \& Turnbull, E. (1998). Cantharellaceae, Gomphaceae and Amyloid-spored and Xeruloid Members of Tricholomataceae (excl. Mycena). British Fungus Flora. Agarics and Boleti 8, pp. 4349. Royal Botanic Garden, Edinburgh. 